\title{
Knowledge Management Processes and Their Impact on Organizational Performance, the Adoption Balanced Scorecard: The Moderating Role of Quality Assurance Standards-An Applied Study on Private Jordanian Universities
}

\author{
Mohammed Abdulsalaam M. S. AL-Hayaly ${ }^{1}$ \& Fayez Jomah S. Alnajjar ${ }^{1}$ \\ ${ }^{1}$ The World Islamic Science and Education University (WISE), Jordan \\ Correspondence: Mohammed Abdulsalaam M. S. AL-Hayaly, The World Islamic Science and Education \\ University (WISE), Jordan. Tel: 962-799-772-007. E-mail: m0799772007m@yahoo.com
}

Received: February 10, 2016

Accepted: March 7, 2016

Online Published: May 22, 2016

doi:10.5539/ijbm.v11n6p70

URL: http://dx.doi.org/10.5539/ijbm.v11n6p70

\begin{abstract}
The study aims to identify the knowledge management processes and their impact on the organizational performance in the Jordanian private universities, the impact of knowledge management on organizational performance was tested next. Finally, the quality assurance standard as a moderating variable was studied.

The study was conducted on Jordanian private universities with a stratified proportionate random sample consisted of (334) faculty members. Questionnaires were distributed to the sample to collect the primary data needed to achieve the study goals.

The results of testing hypothesis showed significant impact of knowledge management processes on the organizational performance, and showed significant impact of the quality assurance standards on improving the impact of knowledge management on the organizational performance, where the coefficient of determination increased from (72.7\%) to $(81.2 \%)$ when studying the impact of combined knowledge management processes on the organizational performance.
\end{abstract}

\section{The study recommended the followings:}

-Universities should seek to establish a formal specialize department to test creative ideas, and then create working groups within universities, and create an incentive system for creative achievements, in order to support the process of knowledge discovery.

-Universities should strive to acquire, develop, and distribute knowledge through the help of international expertise to encourage academic activities that increase the level of knowledge sharing.

-Universities should follow the scientific and practical quality assurance standards because they represent leading indicators of success toward outstanding performance.

Keywords: knowledge management, organizational performance, quality assurance standards, balanced scorecard, private universities in Jordan

\section{Introduction}

Knowledge currently and in the future represents a power source that achieves progress and the competitive advantage, because it considers the most important source for the organizations, societies and the individuals, it helps enhancing skills and experiences, accelerates the innovative and creative distinguish activities which adds value and achieves customers desires, it also makes make the organization at the excellence stage.

Interest in the knowledge source, investing in it and employing it in producing new knowledge's need specialized management, which is knowledge management that contributes to achieving and developing the organizational performance, also works to improve performance through sharing knowledge between the organization's different divisions and units in a way makes it work as one team.

Since universities are a form of organizations, so knowledge management contributes to the development of the universities performance, because the way for teaching and learning, research and discovery is though applying 
knowledge to pursue the academic excellence, from here started the practical attempts to increase the interest in the knowledge source, and using knowledge management in improving the universities performance and increasing the improvement level through caring about the influencing factors, the most important are quality assurance standards in the universities, because quality institutions performance, and their procedures and outputs appropriateness in favor of the society.

From this point his study came to know the effect of knowledge management processes on the organizational performance, and the role of quality assurance standards as a moderate variable in improving this effect.

\section{Importance of the Study}

Importance of this study represents in the important of the surveyed group- the private Jordanian Universitiesthat represent the knowledge production centers and preparing the future's leaders and one of the most important index for the countries progress, also its importance represents in revealing important sides of the role of knowledge management processes in improving the organization performance.

So, increasing the clarity of that role its effects and results in building cognitive account, developed and up-dating, and building knowledge structure, developing the intellectual capital, also it will present to the universities a clear picture about the importance of quality assurance standards, not because they are needed standards should be available, rather because they are factors improve many of the processes and results through studying them with other variables as in this study.

\section{Study Objectives}

The basic objective of this study represents in seeking to know the role of knowledge management processes in the organizational performance in the Jordanian private universities with the presence of quality assurance standards as moderating variable.

\section{Study Problem}

The study problem represents in the organizational performance of the Jordanian private universities in the presence of quality assurance standard as moderating variable to improve the effect of knowledge management processes on the organizational performance.

\section{Hypothesis of the Study}

$\mathbf{H}_{\mathbf{O}}$ 1: There is no effect with statistical significance at significance level $(\mathrm{P} \leq 0.05)$ of knowledge management processes with its dimensions on the organizational performance in the Jordanian private universities.

$\mathbf{H}_{\mathbf{O}}$ 2: There is no effect with statistical significance at significance level $(\mathrm{P} \leq 0.05)$ of quality assurance standards on improving the effect of knowledge management processes on the organizational performance in the Jordanian private universities. 


\section{Study Model}

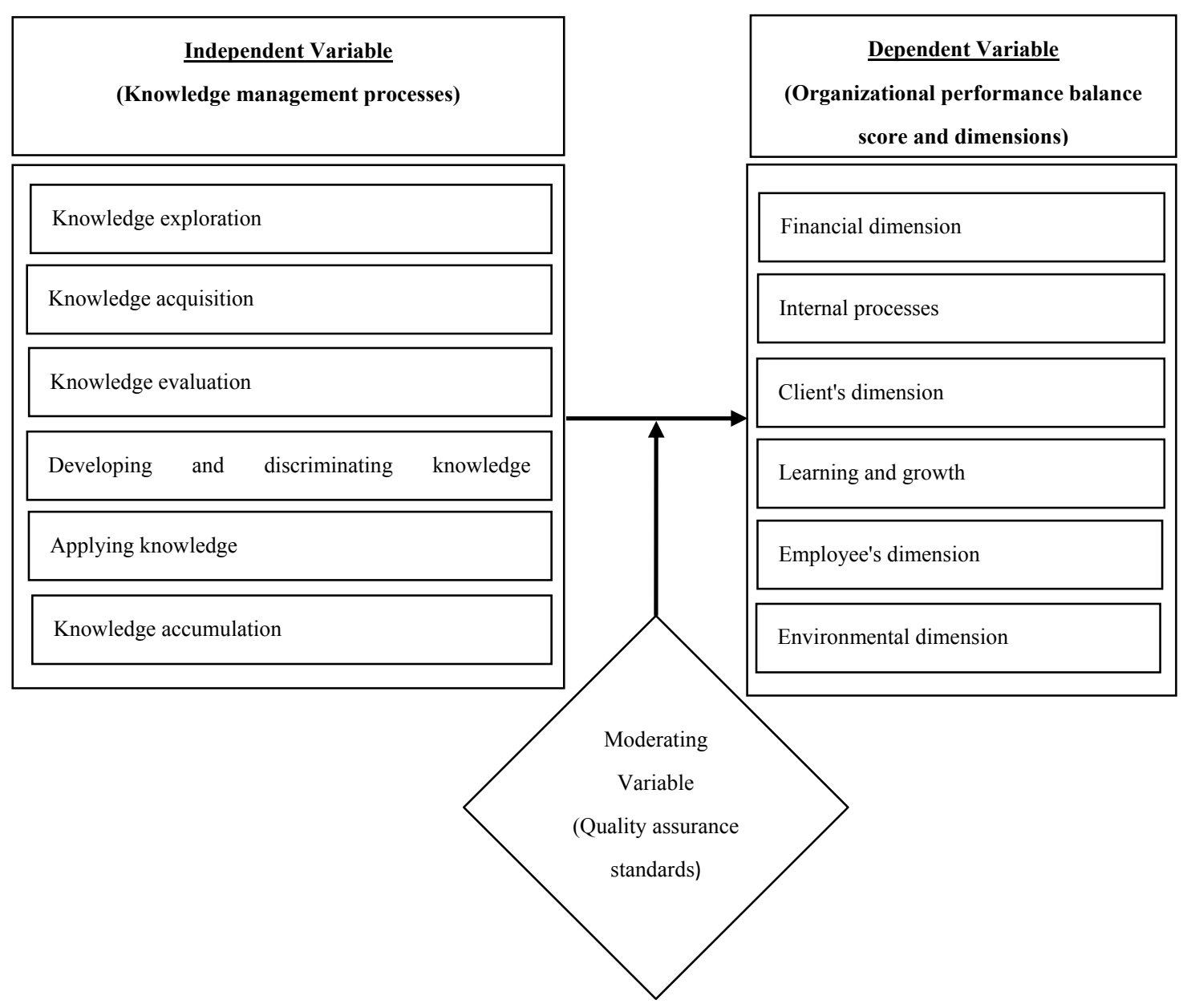

\section{Literature Review}

Slaihat and Mahameed (2013) study reached the presence effect with statistical significance of protecting the knowledge management processes on using the indicators of performance balanced scorecard: (The financial indicators, internal processes, the clients, growth and learning, employees and the environment) in the MSEs in Amman City.

Al-Orabi (2012) study which conducted on the managers, head of divisions who represent the middle management in six companies from the pharmaceutical industry in Jordan reached that the knowledge management level was medium, with the presence of cognitive gap at the level of those significant knowledge's perceived by the top management, and what other employees perceive of knowledge, and the presence of effect of knowledge management on both revenue rate on the assets, and the return rate on property right, also the presence of less influence on the sales growth rate.

The study reached the conclusion that the organizational performance is affected by knowledge management.

Al-Qhiwi (2011) study reached a set of result, including the presence of effect with statistical significance of the elements of knowledge management strategy on achieving the organizational goals by its elements the goals at the organization level and the goals at the individual level in the telecommunication companies.

Noruzy, Daffard, Azhdari, Shirkouki, and Rezazadeh (2013) studies reached the effect of transformational leadership on knowledge management and on the organizational performance, and the presence of indirect positive effect on organizational performance through knowledge management between the industrial companies in Iran (106) companies in which more than (50) employees work in each company.

Seth and Oyugi (2013) study reached the presence of effect of balanced scorecard in its four dimensions in 
higher education institutions in Kyniya, on the organizational performance. Since the clients dimensions explained $(51 \%)$ of the effect, the financial dimension (35\%), internal operations dimension $(31.5 \%)$, learning and growth dimension $(29 \%)$.

Shtibhinyo (2012) study reached the positive effect of performance balanced scorecard aspects on performance execution, and the top management support is the basic determinant of the card application effectiveness, while the expected benefits from the card reflect on the performance of its users in the planning, monitoring \& communications fields in stock Exchange in Thailand.

Kharabsheh, Maghableh, and Sawadha (2012) study reached the presence of effect of all knowledge management practices on the organizational performance variables, in addition, that the pharmaceutical companies adopt knowledge management practices at high level but not high enough. (Emadzade, Mashhaykhi \& Abdar, 2012) study reached and knowledge application on the organizational performance, and the indirect effect of technology and knowledge transformation on then organizational performance, and the other variables, which are the organizational culture, knowledge acquisition and protection did not show any influence on the organizational performance.

Munir and Rohindi (2012) study reached that developing preliminary model for knowledge management system in the university greatly contribute to improving the university performance because it will achieve the development of integrated system on the internet web usable by all beneficiaries, and helping the user reaching the need knowledge, and helping the university preserving all of its documents, and speed of response to any case, situation or decision, supporting the researchers and facilitating the process reaching the required knowledge, leading to the improvement of research quality, and up-dating and developing the learning management system through the link to the world web and achieving the communication with the similar specialties.

Saleh and Huang (2011) Study reached the presence of strong relation between the dimensions of the learning organization and knowledge management processes, and positive effect of the relation the learning organization dimension and knowledge management processes on the university performance in Malaysia, and the leadership and collective learning dimensions were most important and influencing among the seventh dimensions of the organizational learning on the organizational performance.

\section{Theoretical Frame}

\subsection{Knowledge Management}

Knowledge management field has gained popularity in both the businesses and teaching fields, and that contributed to the development of excellence, productivity and technology (Brewer \& Brewer, 2010), for this knowledge management became the concept used generally in the business environment in these days, and usually linked to projects with large budget.

Knowledge management represents the methodological way that enhances the company's capability to improve the capability on making the decision, and the process formulating the strategy (Ooi, 2009). So knowledge management considered strategy helps the organizations to face the competition, globalization, economy and the rapid technological development through creating the effective knowledge that contributes to raising the organizations' intellectual capabilities and achieving the competitive advantage (Kotecki, 2011).

Since there is no common agreement among the researchers and the unified comprehensive definition of knowledge management,

\subsubsection{It Is Possible to Mention Some of Knowledge Management Definitions}

A strategy to confront the increasing challenges in the competition and globalization field, and the technological progress through leveraging the organization' intellectual capabilities and increasing its competitive advantage (Kotecki, 2011, p. 1).

The organized cooperation between the organization's members, technology, structure and processes to add value through re-using knowledge or participating in it, then providing the organization with valuable lessons and better useful applications that are storable in the organizational memory that enables the organizational learning (Mustafa, 2012, p. 14).

Set processes (generating, sharing, discrimination) and the infrastructure (technology, organizational culture, and intellectual capital) and the effective management, and practicing the business used by the organization in the competitive analysis to achieve excellence, superiority and the organizational learning (Delen, Zaim, Kuzey, \& Zaim, 2013). 
Set of practices that help achieving the strategic fit inside the organization through knowledge creation, sharing and discrimination knowledge by using the electronic messages and non-electronic messages such as: using the memos, meetings and e-mail (Analoui et al., 2013).

So, it is possible to identify knowledge management as: A set of intellectual and methodological processes aim at developing the organizational performance through knowledge processing and facilitating its application, and increasing the effectiveness of the organizational learning in away to achieve the competitive advantage.

\subsubsection{Knowledge Management Processes}

Most of the concepts and the management schools see that knowledge management represents processes, and knowledge and information come from internal and external sources do not mean anything without these processes. Knowledge management processes define as the degree to which the company creates in them the knowledge and participate in it, distribute and benefit from it in the job limits (Momeni et al., 2011).

\subsubsection{Knowledge Management Processes Represent in the Following}

Knowledge Discovery - it is the process of discovering new knowledge, this knowledge might be explicit or implicit, discovered from data or information, or by working on previous knowledge, this is done through blending and collecting explicit knowledge's available, data or information to be new set, more complex than the present knowledge (Jaradat et al., 2011, p. 12, p. 134). The axes of this process are three issues: learning, excellence and teams work.

Knowledge Acquisition: When the organization determines the needed level of knowledge, it determines the cognitive gap that should be reached that requires the look inside, and the organization some time demands help from external companies in developing its capabilities to attain the needed knowledge, or buys the advanced technology from the market, also can cooperate through combining its resources by the merging processes or the unification, this can help the organization attains its need of knowledge (Gasik \& Poland, 2011). Knowledge acquisition indicates at the organization ability to develop or forming knowledge sources through the jobs' limits, this comes through enabling the processes and activities to interact, creating, brainstorming, setting the standards and evaluation.

Researchers and studies indicate at strong and positive links between knowledge acquisition and performance measures (Emadzade et al., 2012).

Kotecki (2011, p. 253), Amirkhani et al. (2012, p. 142), and Emadzade et al. (2012, p. 783) studies determined that the axes of knowledge acquisition represent by external sourcing, strategic alliances, mutual agreements, and scientific conferences.

Knowledge Evaluation: This process includes the necessity for knowledge evaluation through the availability of intellectual capital, and developing its account, this is through the presence of strategic perspectives for knowledge management.

Jashapara (2011, pp. 63-89) and ESCCWA, (2004) studies determined the axes of knowledge evaluation process by intellectual capital, strategic management perspectives, and knowledge management strategy.

Knowledge Development and Discrimination: Passing the written knowledge that takes the form storable documents and sharing them between the employees to eb able to use them. This discrimination might be done by the social interaction, knowledge exchange, and change management.

Knowledge Application: Knowledge application indicates at the degree to which the company applies the cognitive source to be shard thorough the Job limits, knowledge application allows the company to generate the revenues for its knowledge and the ability to benefit from knowledge base with the importance in decision making and problems solving, and to response more effectively to the environmental changes. Then knowledge is used in the context which enables the users to learn, then producing new knowledge's.

Many organizations encourage the organizational learning of the individuals in which it is possible to apply knowledge to the initiatives, such as developing new products, improving performance, speed of innovation, and market need, because it affects the organizational performance, its should be used to support the company's processes (Alhawari, Talet, \& Al-Jarrah, 2011). (Golden, 2009, pp. 152-153; Cho, 2011, p. 8) determined the axes of applying knowledge by empowerment, decision marking and the organizational routine.

Knowledge Accumulation: Knowledge evaluation and accumulation process confirms the building of cognitive storage, determining and distributing knowledge in the organization to achieve excellence. (Mciver \& Hall, 2011, p. 185; Amirkhani et al., 2012, p. 142) studies determined the axes of this process by the cognitive storage knowledge map and excellence. 


\subsubsection{The Universities for Knowledge Management}

There is an increasing perception of the importance of knowledge management by opinions leaders, the academics and the scientists worldwide, because its contributes to enhancing the tacit energy for innovation and creation (Yaseen, 2007, pp. 46-47) sin cense universities are the en-capture of the higher education and have the strategic role in investing in the tacit energies and increasing innovation and creation, the need of the universities for knowledge management became clear, for the following reasons:

Knowledge management contributes to increase the innovation and creation initiatives by the teaching staff members in the universities.

Knowledge management contributes to enhance the psychological empowerment of the teaching staff members in the universities. Since (Hamid, Ali, Azizollah, \& Aghabaei, 2012) studies showed the presence of positive correlation with statistical significance between knowledge transfer and psychological empowerment of the teaching staff members.

Increases the university capability to contribute to the economic development and making it more effective in playing the fruitful economic role through serving the stakeholders and the business owners, and developing the human capital and the infrastructure to use technology appropriately (Brewer \& Brewer, 2010).

Knowledge management works to develop the university performance and links it directly to the society, knowing the need of the marketplace, setting the relevant curricula and the effective teaching methods that serve the society, especially through the internet webs that facilitate knowledge sharing with the society, and the rapid communication with it (Cho, 2011, p. 191, Munir \& Rohindi, 2012).

\subsection{Organizational Performance}

Organizational performance concept is based on the idea that the organization is a voluntary association of production assets (human, financial and capital) and performance responsibility is to create value, and it considers a method of achieving value creation, determining the measurement dimensions, preparing the controller who determines the value, and finally determining the relevant opportunities (Carton, 2004, pp. 3-4).

Some of the definition that mentioned organizational performance is the following:

Determining the stakeholders, improving the basic processes, relevant allocation of the human, material, financial and information resources, and effective and able management to set a clear and understandable strategy by the workers (Kottler, 2000, p. 40). Financial honesty by using the organizational indicators (Mitchell, 2002, p. 1).

Efforts, activities, processes, behaviors, and actions performed by the individual or groups from which the organization consists regardless of their levels and characteristics, the source of these activities might by equipment, financial or joint work (Ho, 2008, p. 1238).

Activities, products, perfection, results, influences or accomplishing the organization's tasks and goals.

It is possible to say that the organizational performance concept represents the final results for the organization, and measuring these results is necessary to illustrate the reality and the position of the organization in the market, and the nature of its internal processes track.

\subsection{Concept of Balanced Performance Scorecard}

Balanced performance card represents a system for measuring performance based on evaluating the organization development and growth, and enhancing its abilities with the goal to improve the customers satisfaction and the organizational effectiveness and efficacy (Poureisa, Ahmadgourabi, \& Efteghar, 2013). It is a strategic instrument helps the organization to bridge the gap between the strategy and the executive producers because it contains the financial and non-financial elements from one side, and can be used at a wide range of multiple fields like the businesses industry, the government and the non-for-profit organizations from the other side (Asa, Prasad, \& Htay, 2013).

\subsubsection{Development of Balanced Performance Scorecard}

The basic for creating and developing the balanced performance scorecard as an instrument for measuring is the assumption that the traditional performance measurement systems based on the financial according procedures are no longer enough as performance indicators in the rapid changing business environment (Asa et al., 2013).

By the end of 1980, many articles published in the European and American administrative Journals criticizing the methods for evaluating the effectiveness of the institutional performance. 
In the year 1978 the administrative and accounting researches in the American society showed that $(60 \%)$ of 260 financial and executive directors from (64) companies in U.S.A were dissatisfied with the methods for measuring the performance of their companies (Poureisa et al., 2013).

Peter Dracker has warned in 1954 about this topic, and indicated to the presence of one possible solution, which is introducing balanced groups of procedures: Market situation, innovation, productivity, material and financial resource, profitability, performance, development management, employees performance, the attitude, and general responsibility, are the relevant standards for performance (Neely, 2005).

Kaplan and Norton proposed in 1992 the balanced performance scorecard through group of researches in (12) companies, the stated that for the companies to evaluate their performance should not focus only on the financial sides, rather they should focus on the financial and non-financial sides related to their performance towards the processes, clients learning and growth. (Kaplan \& Norton, 1992; Shutibhinyo, 2012).

\subsubsection{Dimensions of the Balanced Performance Score Card}

Balanced performance card consists of six dimensions; they are (Seth \& Oyugi, 2013; Asa et al., 2013; Slaihat \& Al-Mahmameed, 2013, p. 12; Husein, 2010, p. 15).

The Financial Dimension-This dimension concerns in establishing a sustainable organization growth in the value of the shareholders rights, evaluating liquidity and profitability, then the work to improve the operational performance to achieve the financial success. The indicators of this dimension are : increasing the sales volume, acquiring new customers, revenues growth and return on investment and equity, pay-back periods, and the added market value.

Internal Processes Dimension: This dimension focuses on determining the basic processes that form the goods and services and to guarantee their delivery Just-in-time with the relevant quality and good performance. The indicators of this dimension are: innovation rates, creativity rates, service \& quality procedures, quality standards, competency levels, costs reduction, safety and globalization.

Customers Dimension: This dimension confirms the customers need, and the work to meet them timely, quality and place through surveying the customers opinions, the indicators of this dimension are: Time, quality, customers satisfaction, customers loyalty, market share, customers complaints and the costs.

Learning and Growth Dimension: This dimension concerns about determining the organization capability to continue in the perpetual improvement by focusing on the intangible assets which contributes to support the internal processes capabilities towards excellence.

The indicates of this dimension are : skills development, customer satisfaction about training, providing the training opportunities, training costs, return on training, efficacy of the training program, developing the workers productivity.

Workers Dimension: This dimension focuses on the employee satisfaction about the services provided to them indicators of this dimension are : employees turnover, promotion opportunities, preserving safety and health, employees empowerment, dedicating the authorities, internal communications, encouraging the achievement of the individual goals.

Environment Dimension: This dimension focuses on the organization commitment towards the environment and preserving it as social responsibility, the indicators of this dimension are: environmental training and enlighten, commitment to the international standards for the environment, care about the environmental problems, documenting the environmental problems, using strategies to preserve the environment, and the commitment to the social responsibility terms.

It is noted that the indicators differ from country to another and from university to another, this might attribute to the difference in the academic work environment from one country to another, and sometime the difference takes place in the same country because the organizational environment influences the work inside the university.

\subsection{Quality Assurance}

\subsubsection{Quality Assurance Goals}

Quality assurance goals were determined by the Board of Accreditation of the Higher Education Institutions in Jordan as follows: (Higher Education, 2009)

Encouraging excellence in the Higher Education Institutions in Jordan through developing simulations and evidences to evaluate the educational effectiveness in them.

Encouraging the institutional improvements in the educational process through continuous self-evaluation 
practiced by the institution.

Assuring the educational society and the general society and other local, regional and international institutions that the institution under concern has specific and relevant goals and it prepared the relevant conditions through which it is possible to achieve its goals and message effectively, and it keeps as table level of achievements of these goals and message, and has organizational structures in which work qualified and effective staffs, and it provides the financial material and human support that makes the person expect its sustainable excellent and effective performance.

Encouraging the positive competitive spirit between the Jordanian higher education institutions for excellence in their inputs, processes, and outputs according to the requirements of the local, regional and global society, and the spirit of quality era, globalization and knowledge economy.

\subsubsection{Quality Assurance Elements}

Quality assurance elements are a set of components able to enhance work towards achieving quality in the educational organizations (Al-ani, Al-qazaz, \& Korele, 2002). Ehlers (2009) mentioned that quality assurance elements are four, include the following:

Quality knowledge - Expresses the abilities to develop and apply the quality and its updating strategies in the educational field.

Quality experiences - Expresses the ability to use quality strategies with the determined orientation.

Quality excellence - expresses the ability to modify or the innovative adjustment the goals and developing the strategies, the means and the goals.

Quality analysis - expresses the ability to analyze the quality development process in the light of the experiences to fit with the environment and the current position for evaluating, to help the decision markers in evaluating the different goals and the present situation for evaluation.

\subsubsection{Quality Assurance Standards}

Following is the illustration of the $12^{\text {th }}$ quality assurance standards in the Jordanian higher education institutions accredited by Council Board of Accreditation the higher education intuitions (2009, pp. 70-29).

The institutions vision, message, goals, planning, the educational programs and their effectiveness, students and students services, Teaching staff, scholarships, scientific research, innovations, the library and information sources, governance and management, financial resources, material resources, institutional integrity, interaction with the society \& quality assurance management. The mentioned standards were adopted in the study as a moderating variable.

\subsubsection{Quality Assurance in the Universities and Its Requirements}

Quality assurance has many concepts, including it is the translation of the needs and expectations of the graduates from the university to specifications and specific standards in the graduate to be the basic to generalize and implement the teaching programs with their continuous development (Othman \& Othman, 1997, p. 367).

White the authority for accreditation in the higher education institutions in Jordan sees quality assurance as the process in which confirming performance quality of the educational institutions, and the soundness of its procedures, and the quality of its outputs in away makes the academic and educational society and the general society trust it (Higher Education, 2009).

\subsection{Relationship between Knowledge Management and Organizational Performance}

The relationship between knowledge management and organizational performance is a strong relationship explained by the following points:

Knowledge management contributes to the improvement of the organizational management field in its different sides (Learning and growth, internal processes, financial perspective, and care about the customer (Matin et al., 2010).

Knowledge management contributes to building the organizational capabilities building through improving the skills and the knowledge of the working individuals, improving the work efficiency, increasing productivity, increasing participation which in turn reflects on the development of the organizational performance (Kotecki, 2011, pp. 110-117).

Knowledge acquisition and application processes increase the level of the organizational performance and improve the results of the organizational effectiveness (Emadzade et al, 2012, p. 781). 
Knowledge management represents value management in improving performance, so the managers seek to implement knowledge management program to gain the profit, advantage, and increasing productivity.

Practicing knowledge management has great effect on the organizational performance, especially on the success of new product, and improving the financial performance (Kharabsheh, 2012).

Knowledge management processes represent the most important factor to create added-value to the performance which forms added-value to the organization revenues and to the economy.

\section{Study Methodology}

\subsection{Type and Nature of the Study}

From the purpose this study considers (Explanatory), and from its nature considered (Applied), also the study depended on the survey strategy, since a relevant stratified random sample has been extracted from the targeted population.

\subsection{Study Population}

Study population consisted of the Jordanian Private Universities, single faculty university is excluded because it has no deans council, so the number of the universities under study is (15) private universities, in which (2567) individuals work in it (Annual statistical report about the higher education in Jordan, 2011/2012).

\subsection{Study Sample}

A relevant stratified random sample has been drowning from the universities that form the study population, study sample number reached (334) individuals according to (Sekaran \& Bougie, 2009; Alnajjar et al., 2013), since the study population divided in to (15) classes according to the universities number accredited in the study, as in the following table:

Table 1. Statistics

\begin{tabular}{|c|c|c|c|c|}
\hline No. & University Name & $\begin{array}{l}\text { Number } \\
\text { The } \\
\text { Teaching } \\
\text { Staff }\end{array}$ & $\begin{array}{l}\text { Sample } \\
\text { Withdrawn }\end{array}$ & Number \\
\hline 1 & Amman Arab University & 93 & 12 & \\
\hline 2 & Middle East University & 129 & 17 & \\
\hline 3 & Private Al-Zaituna Jordanian University & 312 & 41 & \\
\hline 4 & Private Amman Ahleya University & 239 & 31 & \\
\hline 5 & Private Irbid Ahleya University & 83 & 11 & \\
\hline 6 & Private Applied Sciences University & 285 & 37 & \\
\hline 7 & Prices Symaya University for Technology & 85 & 11 & \\
\hline 8 & Petra University & 249 & 32 & \\
\hline 9 & Jadara University & 100 & 13 & \\
\hline 10 & Zarqa University & 253 & 33 & \\
\hline 11 & Isra University & 210 & 27 & \\
\hline 12 & Jarash University & 178 & 23 & \\
\hline \multirow[t]{3}{*}{13} & Private Philadelphia University & 237 & 31 & \\
\hline & Private National Ajloon University & 59 & 8 & \\
\hline & Total & 2567 & 334 & \\
\hline
\end{tabular}

The questionnaires were distributed to the study sample (334) questionnaire, and (297) questionnaires were retrieved, after testing them it was found that (290) of them valid for analysis, this number forms $(86.83 \%)$ of the total distributed questionnaires.

\subsection{Unit of Analysis}

Unit of Analysis included the faculty deans, their deputies, had of divisions, teaching staff members in the Jordanian private universities.

\subsection{Data Collection Methods}

They Study depended on two basic sources for collecting data needed for the study: 


\section{Secondary Data}

included the books, periodic Books, university thesis, scientific researches, theoretical and applied studies related to the study topic, and the published articles in the accredited databases, the different data and references were documented based on the American Psychological Association System - APA (2010).

\section{Preliminary Data}

The questionnaire has been designed and developed as the basic instrument for collecting the preliminary data and information from the study sample, depending on the previous Arabic and foreign studies, and theoretical frame related to the study topic. The questionnaire consisted of four parts, the first part consisted of the demographic data and characteristics specific to the study sample.

While the second part included the independent variable in this study (knowledge management) since it is divided into six sub-variables (knowledge exploration, knowledge acquisition, knowledge evaluation, knowledge development and discrimination, knowledge application, and finally knowledge accumulation, while the third part included the dependent variable (organizational performance) it is also divided to a number of sub-dimensions, which are: (financial dimension, internal processes dimension, customers dimension, learning and development dimension employees dimension from inside (educational service providers, and social consultations) finally the (environment dimension), the fourth part of the questionnaire included the moderating variable (quality assurance standards), likret five point scale is adopted to measure the sample individuals responses to the study variable questions.

\subsection{Study Instrument}

In order to achieve the study goals the researchers used the questionnaire as the study instrument, they designed and developed the questionnaire after benefiting from the previous studies related to the study topic, like university theses and dissertations, and published scientific researches, also benefiting from the opinions of those with major and knowledge about the study topic.

After reviewing the different opinions, the questionnaire presented in its final form.

1. First part included the demographic information about the study sample.

2. Second part the independent variable, (knowledge management processes) based on: (ESQWA, 2004, pp. 8-14; Jashapara, 2011, p. 12, pp. 68-89; Amirkhani et al., 2012; Kotecki, 2011, pp. 73-78; Cho, 2011, p. 133).

3. Third part the dependent variable (organizational performance) based on (Husein, 2001, 15; Seth \& Oyugi, 2013; Slaihat \& Al-Mahameed, 2013, p. 12; Cho, 2011, pp. 14-18; Kaplan \& Norton, 1992, p. 78; Kaplan \& Norton, 2008, p. 11).

4. While the moderating variable (quality assurance standards) were determined based on (Accreditation Board of the Higher Education Institutions, The Guide for quality Assurance standards and procedures in the Jordanian Higher Education Institutions, 2009).

\section{Study Instrument Validity}

The questionnaire has been subject to arbitration to test its validity and ability to measure what it has designed to measure, since its is presented to many of the Jordanian Universities Prophesiers with specialty in the study topic, (21) university doctors.

\section{Testing study Instrument Validity}

Cronbach's Alpha internal consistency coefficient was calculated, and knowledge exploration reached (0.874), knowledge acquisition $=0.879$, knowledge offering $=0.893$, knowledge development and dissemination $=0.879$, knowledge evaluation and accumulation $=0.912$, in addition to alpha value for all items of knowledge management together was (0.972), Financial dimension $=0.79$, internal processes $=0.903$, clients dimension $=$ 0.901 , learning and development $=0.898$, employees dimension $=0.873$, environmental dimension $=0.922$, and alpha value for all of the items related to organizational performance together was $(0.951)$, while alpha value to quality assurance standards reached (0.963), so all the values greater than $(0.70)$, this is an indicator to consistency between the study instrument items, and study instrument reliability, to conduct the statistical analysis (Alnajjar et al., 2013, p. 241).

Testing the model's stability: To test the extend of the study data suitability to analyze the linear regression. The Autocorrelation he been tested.

From the regression terms data should be free from the autocorrelation problem known by the presence of correlation between random error limits in the regression model, from which results bias in the (estimated 
parameters) so the weakness in the model's ability to predict . this can be assured by conducting (Durbin-wet son Test), this test depends on (D-W) Tabulating the sample size (n), number of its variables (k) with (D-W) calculated result, since there are two statistical tabulated values, minimum value $\mathrm{dl}$ and maximum value du and rejecting the presence of auto correlation problem, if (D-W) value outside the limits- minimum and greater values (Montgomery, Peck, \& Vining, 2001).

Table 2. Durbin-Watson test

\begin{tabular}{lllll}
\hline Hypothesis & D-W calculated value & dl & du & Result \\
\hline $\mathrm{H}_{\mathrm{o}} 1$ & 1.891 & 1.707 & 1.831 & No autocorrelation \\
\hline
\end{tabular}

We see from the table that (D-W) values for the mentioned hypothesis outside the limits of the minimum and maximum values, which indicates the absence of autocorrelation problem in the data, which means there is no correlation between the random error limits in the regression model.

Table 3. Data analysis and testing the hypothesis

\begin{tabular}{|c|c|c|c|c|c|}
\hline Gender & Freq. & $\%$ & Occupational level & Freq. & $\%$ \\
\hline \multirow{2}{*}{ Male } & \multirow{2}{*}{238} & \multirow{2}{*}{82.1} & Dean & 27 & 9.3 \\
\hline & & & Dean deputy & 8 & 2.8 \\
\hline \multirow{2}{*}{ Female } & \multirow{2}{*}{52} & \multirow{2}{*}{17.9} & Head of division & 73 & 25.1 \\
\hline & & & Teaching staff member & 182 & 62.1 \\
\hline Total & 290 & 100 & Total & 290 & 100 \\
\hline
\end{tabular}

Table 4. Frequencies and the percentages of the study sample demographic

\begin{tabular}{llllll}
\hline Academic & Freq. & $\mathbf{\%}$ & Experience & Freq. & \% \\
\hline Professor & 29 & 10.0 & Less than 5 years & 89 & 30.7 \\
Associate Prof. & 72 & 24.8 & 5 years- less than 10 years & 87 & 30.0 \\
Assistant Prof. & 150 & 51.7 & 10 years and less than 15 years & 37 & 12.7 \\
Doctor & 39 & 13.5 & 15 years and more & 77 & 26.6 \\
Total & 290 & 100 & Total & 290 & 100 \\
\hline
\end{tabular}

It is clear from the table that the males represent (82.1) of the study sample, while the age category 30 less than 40 years, 40 -less than 50 years are the larger by $(32.4 \%)$, also the associate Prof. category formed the greater percentage, $(51.7 \%)$, experience category (less than 5 years) formed the greater percentage $(30.7 \%)$, while teaching staff member category formed $(62.8 \%)$, this consists with the natural administrative pyramid in the universities, and those who attended (1-less 5 conferences) reached (36.9\%).

\subsection{Testing the Study Hypothesis}

$\mathbf{H}_{\mathbf{0}}$ 1: There is no effect with statistical significance at significance level $(\mathrm{P} \geq 0.05)$ of the knowledge management processes on the organizational performance in the Jordanian private universities.

To test the first basic hypothesis, and determining which of knowledge management variables had the prominent effect on the organizational performance, stepwise multiple regression was applied, and the results, were are follows:

Table 5. ANOVA test

\begin{tabular}{lllllll}
\hline \multirow{2}{*}{ Model } & \multicolumn{2}{l}{ Model Summary } & \multicolumn{5}{c}{ ANOVA } \\
\cline { 2 - 7 } & $\mathrm{R}$ & $\mathrm{R}^{2}$ & Std. error & df. & F. & Sig. \\
\hline 1 & 0.802 & 0.643 & 0.427 & 1 & 515.957 & 0.000 \\
2 & 0.829 & 0.687 & 0.400 & 2 & 314.358 & 0.000 \\
3 & 0.845 & 0.714 & 0.383 & 3 & 237.287 & 0.000 \\
4 & 0.853 & 0.727 & 0.375 & 4 & 189.314 & 0.000 \\
\hline
\end{tabular}


Table 6. Coefficients

\begin{tabular}{|c|c|c|c|c|}
\hline & Model & $\beta$ & T value & Sig. \\
\hline 1 & Knowledge application & 0.802 & 22.715 & 0.000 \\
\hline \multirow[t]{2}{*}{2} & Knowledge application & 0.547 & 10.568 & 0.000 \\
\hline & knowledge development and discrimination & 0.331 & 6.339 & 0.000 \\
\hline \multirow[t]{3}{*}{3} & Knowledge application & 0.368 & 6.094 & 0.000 \\
\hline & knowledge development and discrimination Evaluation and & 0.283 & 5.617 & 0.000 \\
\hline & accumulation & 0.273 & 5.166 & 0.000 \\
\hline \multirow[t]{4}{*}{4} & Knowledge application & 0.312 & 5.115 & 0.000 \\
\hline & knowledge development and discrimination & 0.210 & 3.967 & 0.000 \\
\hline & Knowledge evaluation and accumulation & 0.255 & 4.921 & 0.000 \\
\hline & Knowledge acquisition & 0.177 & 3.700 & 0.000 \\
\hline
\end{tabular}

When reviewing the table we find that the resulting the first model from stepwise analysis indicates that the variable (knowledge application) explained $(64.3 \%)$ of the resulting total variance in the organizational performance, the percentage of explaining the total variance in the organizational performance reached (68.7\%), when adding knowledge development and discrimination to (knowledge management) in the second model, while the percentage of explaining the total variance in the third model, the percentage of explaining the total variance in the organizational performance reached (71.4\%), when adding knowledge evaluation and accumulation.

But the percentage of explaining the total variance in the organizational performance reached $(72.7 \%)$, when adding knowledge acquisition in the fourth model. Since (F) different levels in the four models is within significance level $(\mathrm{Sig}=0.000)$, this confirms the regression significance.

Also, found that $(\beta)$ values in the four models at (t.) different levels are at significance level $(\mathrm{Sig}=0.000)$ for all variables within the four models of the stepwise regression, and came less than (0.05). This confirms the significance of regression coefficients, which indicates that the variable effect on those models with statistical significance.

Based on the above mentioned, we can confirm the rejection of the first null hypothesis and accepting the alternative hypothesis: There is an effect with statistical significance at significance level $(\mathrm{P} \leq 0.05)$ of knowledge management on the organizational performance in the Jordanian Private Universities.

$\mathbf{H}_{\mathbf{0}} \mathbf{2}$ There is no effect with statistical significance at significance level $(\mathrm{P} \leq 0.05)$ for quality assurance variables on improving the effect of knowledge management process on the organizational performance in the Jordanian Private Universities.

To test the second basic hypothesis, Hierarchical Multiple Regression has been used, and the results were as follows:

Table 7. Results for second basic hypothesis test

\begin{tabular}{|c|c|c|c|c|c|c|c|}
\hline \multirow{2}{*}{ Dependent variable } & \multirow{2}{*}{ Independent variables } & \multicolumn{3}{|c|}{ First Step } & \multicolumn{3}{|c|}{ Second Step } \\
\hline & & $\beta$ & t-Value & Sig. $t$ & $\beta$ & t-Value & Sig. t \\
\hline \multirow{11}{*}{$\begin{array}{l}\text { Organizational } \\
\text { Performance }\end{array}$} & Knowledge exploration & 0.081 & 1.515 & 0.131 & 0.004 & 0.083 & 0.934 \\
\hline & Knowledge acquisition & 0.163 & 3.071 & 0.002 & 0.067 & 1.474 & 0.141 \\
\hline & Knowledge evaluation & -0.038 & 0.602 & 0.547 & -0.020 & 0.374 & 0.709 \\
\hline & $\begin{array}{l}\text { Knowledge development and } \\
\text { discrimination }\end{array}$ & 0.208 & 3.731 & 0.000 & 0.117 & 2.472 & 0.014 \\
\hline & Knowledge application & 0.295 & 4.732 & 0.000 & 0.190 & 3.584 & 0.000 \\
\hline & $\begin{array}{l}\text { Knowledge evaluation and } \\
\text { accumulation }\end{array}$ & 0.254 & 4.639 & 0.000 & 0.154 & 3.815 & 0.001 \\
\hline & Quality Assurance Standards & & & & 0.488 & 11.063 & 0.000 \\
\hline & $\mathrm{R}^{2}$ - Determining Coefficient & 0.729 & & & 0.812 & & \\
\hline & $\Delta \mathrm{R}^{2}$ & 0.729 & & & 0.083 & & \\
\hline & $\Delta \mathrm{F}$ & 126.738 & & & 122.395 & & \\
\hline & Sig. $\Delta \mathrm{F}$ & 0.000 & & & 0.000 & & \\
\hline
\end{tabular}


The table shows (036.5) results of the Hierarchical Multiple Regression based on two models, since the results of the first model reflected on the first step, the presence of the effect with statistical significance of the independent variables represent by (knowledge management processes) together on the organizational performance since $\mathrm{F}$ value $=126.728$, 1 with significance level $\mathrm{Sig} F=0.000$, which is less than $(0.05)$, and determination coefficient $\left(\mathrm{R}^{2}=0.729\right)$ indicates that (knowledge management processes) collectively explained (72.9\%) of the resulting variance in the (organizational performance).

In the second step: (quality assurance standards) variable is inserted in the regression model, $\mathrm{R}^{2}$ value increased by $(8.2 \%)$, this percentage with statistical significance, since $\Delta \mathrm{F}$ value $=122.395$, and ( $\mathrm{Sig} \Delta \mathrm{F}=0.000$ ) which is less than $(0.05)$, and $(\beta=0.488)$ at (quality assurance standards) and $(\mathrm{t}=11.063)$, with $(\mathrm{Sig}=0.000)$ this confirms the significance effect of quality assurance standards on improving the effect of knowledge management processes on the organizational performance, since the total variance explanation percentage improved by (8.3\%) to raise from $(72.9 \%)$ to $(81.2 \%)$. So, rejecting the second null basic theory and accepting the alternative hypothesis, this states:

There is an effect with statistical significance at significance level $(\mathrm{P} \leq 0.05)$ of the quality assurance standards on improving the effect of knowledge management processes on the organizational performance in the Jordanian Private Universities.

\section{Results}

Results of testing the hypothesis showed the presence of significant effect of knowledge management on the organizational performance, and applying knowledge process had the most prominent effect, since it explained (64.3\% of the resulting variance in the organizational performance, and when adding knowledge development and discrimination to knowledge application, this percentage of explaining the total variance in the organizational performance reached $(68.7 \%)$ while the percentage of explaining the total variance reached (71.4\%) when adding (knowledge evaluation and accumulation) to (knowledge application and knowledge development and discrimination) and when adding knowledge acquisition the percentage reached (72.7\%), and no effect appeared for (knowledge exploration and knowledge evaluation) on the organizational performance.

These results clarity that the use of knowledge management will contribute to increasing the university performance, but there are variances in the effect of each process of knowledge management processes individually on the performance reached the limit discouraging, which is the absence of effect of the two dimensions (knowledge exploration and knowledge evaluation) on the organizational performance. It is worth mentioning that this result requires re-viewing to activate the effect.

So, this result agrees with (Slaihat \& Al-Mahameed, 2013), regarding the presence of effect with statistical significance of practicing knowledge management processes on using the balanced performance scorecard in directors, also agreed with (Al-Orabi, 2012) study, regarding that the organizational performance influence by knowledge management, also agreed with (Al-Qhaiwi, 2011) study regarding the presence of effect with statistical significance of the components of knowledge management strategy on accomplishing the organizational goals, and agreed with (Seth \& Oyugi, 2013) about the presence of effect of the balanced card estimates with its four dimensions on the organizational performance and with (Kharabsheh et al., 2012) in the presence of effect of all knowledge management practices on organizational performance variables, and with (Emadzada el al., 2012) study about the presence of direct effect of the organizational structure and knowledge application on the organizational performance, and the presence of indirect effect of technology, knowledge transfer on the organizational performance, and with (Munir \& Rohind, 2012) study about the development of a model for knowledge management system greatly contributes to improving the university performance and agreed with (Saleh \& Huang, 2011) study about the presence of positive effect of the relation between the learning organization dimensions and knowledge management processes on the university performance.

From the researcher's opinion, the reason for the great agreement is due to the knowledge management processes effectiveness, since it is one of the essential components for the success of the organizations including the universities, in addition, knowledge management represents influencing environmental power in changing a lot of the results of the organizational function, and increases transparency level through documentation and sharing knowledge.

Hypothesis Test Results showed the presence of significant effect of quality assurance standards on improving the effect of knowledge management processes on the organizational performance, since the value of the determination coefficient increased from (72.9\%) to (81.2\%) when studying the effect of knowledge management processes collectively on the organizational performance, these results confirm the importance of quality assurance standards as a moderating variable on increasing the effect of knowledge management on the 
university performance.

\section{Recommendations}

Universities should adopt the policies able to make knowledge management process of its most important priorities, through training the interest of the universities from focusing on increasing the capital and workforce to the focus on building the cognitive structure which increases its intellectual capital through adopting methodological mechanism based on applying knowledge management system to develop the organizational performance by sending their teaching staff member in scholarships to well-known universities with high international rank, also encouraging teaching staff members to participate in the advanced scientific courses.

The pursue to set the formal structure specialized in the universities to test the innovative ideas, forming work teams, allocating the good rewards when achieving innovative accomplishments with the goals to support knowledge exploration process.

The necessity for seeking knowledge acquisition, development and discrimination, through the use of external expertise, and encouraging the academic activities that increase knowledge sharing, like holding conferences, also make the research partnerships, tensing with the global universities.

Performing the needed procedures for knowledge evaluation, to determine the cognitive gap, and to analyze the present cognitive level, and determining the targeted level to formulate knowledge management strategy.

Conducing the referential comparison process by the universities to determine the level of its success in applying knowledge management processes comparing to other universities, and the universities should process cognitive maps about success and failure stories in other universities,

Re studying the currently used measures by the universities as indicators to performance measurement, making them more relevant for the balanced performance card dimensions, this will requires conducting workshops in which participate the academic and administrative leaders to prepare measures and indicators lists.

The necessity to raise the organizational performance level through the periodic evaluation of performance level and determining the deviations as soon as possible and making the needed modification, adding the new methods, this requires following-up the development in the global universities in addition to direct knowledge about the market needs.

The practical and scientific commitment by the universities to the quality assurance standards, because they represent the indicators of the excellent organizational performance success.

\section{References}

Al-ali, A, Qandeelji, A., \& Alomari, G. (2012). An approach to knowledge management. Jordan, Amman: Dar Al-Maseera

Al-ani, K., Alqazaz, I., \& Korele, A. (2002). Total quality management and ISO 9001 requirements. Iraq, Baghdad: Al-Ashqar Print.

Alhawari, E., Talet, A., \& Al-Jarrah, M. (2011). Development of conceptual framework for knowledge management process. Journal of Modern Accounting and Auditing, 7(8), 864-877.

Alnajjar, F., Al-najjar, N., \& Al-Zoubi, M. (2013). Scientific research methods. Applied perspective. Jordan, Amman: Dar Al-hamed for Publication and Distribution.

Al-Orabi, F. (2012). Knowledge Management Role in Enhancing the organizational performance. Master Thesis, Al-Albayt University Al-Mafraq, Jordan.

Al-Qhiwi, L. (2011). Role of knowledge management strategy in achieving the organizational Goals for the service companies. Doctorate Dissertation, Amman Arabic University for Higher Studies, Amman, Jordan.

American Psychological Association. (2009). Publication manual of the American psychological association (6th ed.). Washington, DC: American Psychological Association.

Amirkhani, A., Tajmirriahi, J., \& Mohammad, M. (2012). Assessing the effectiveness of knowledge management in empowering and development of human resources: A case study on Ati Luleh Sepahan Company. Interdisciplinary Journal of Contemporary Research in Business, 3(12), 131-147.

Analoui, B., Deloriert, F., \& Sambrook, S. (2013). Leadership and knowledge management in UK ICT $\begin{array}{lllll}\text { organizations. Journal of } & \text { Managemant }\end{array}$ http://dx.doi.org/10.1108/02621711311286892

Annual Statistical Report about higher education in Jordan for the year 2012/2012. Ministry of Higher Education 
and Scientific Research- Jordan.

Asa, R. A., Prasad, N. S., \& Htay, M. M. (2013). Balanced scorecard: a paradigm measure of business strategy and firm performance. International Journal of Scientific \& Technology Research, 2(4), 121-125.

Brewer, P., \& Brewer, K. (2010). Knowledge management, human resource management, and higher education: A theoretical model. Journal of Education for Business, 85, 330-335. http://dx.doi.org/10.1080/08832321003604938

Carton, R. B. (2004). Measuring organizational performance: An exploratory study. PhD Dissertation, The university of Georgia.

Cho, T. (2011). Knowledge management capabilities and organizational performance: An investigation into the effect of knowledge infrastructure and processes or organizational performance. PhD Dissertation, University of Illinois.

Delen, D., Zaim, H., Kuzey, C., \& Zaim, S. (2013). A comparative of machine learning system for measuring the impact of knowledge management practices. Decision Support Systems, 54(2), 1150-1160. http://dx.doi.org/10.1016/j.dss.2012.10.040

Ehlers, U. D. (2009). Understanding quality culture. Quality Assurance In Education Journal, 17(4), 343-363.

Emadzade, M., Mashayekhi, B., \& Abdar, E. (2012). Knowledge management capabilities and organizational performance. International Journal of Contemporary Research In Business, 3(11), 781-790.

ESCWA (Economic and social committee for West Asia). (2004). Knowledge management methodology Empirical comparison in central sectors in the ESCWA countries members-United Nation. New York.

Gasik, S., \& Poland, W. (2011). A model of project knowledge management. Project Management Journal, 42(3), 23-44. http://dx.doi.org/10.1002/pmj.20239

Golden, C. (2009). Knowledge management and historically black colleges and universities. Dessertation of Doctor of philosophy applied management science. Walden University.

Hamid, R., Ali, N., Azizollah, A., \& Aghabaei, R. (2012). The analysis of knowledge conversion process in the university and ITS relationship with psychological empowerment among faculty member. Interdisciplinary Journal of Contemporary Research In Business, 4(1), 920-934.

Higher Education Institutions Accrediting Authority. (2009). Guide for Quality Assurance Procedures and Standards in the Jordanian Higher Education Institutions, Ministry of Higher Education and Scientific Research, Jordanian Private Universities and Higher Education Institutions.

Ho, L. (2008). What effects Organizational performance ? the linking of learning and knowledge management. Industrial Management \& Data System, 108(9), 1234-1254. http://dx.doi.org/10.1109/ICEE.2010.499

Husein, Z. (2010) Strategic model multi dimensional for performance Evaluation (Proposed Frame). Conference of the Arabic Organization for Administrative Development, Cairo - November.

Jaradat, N., Al-Ma'ani, M., \& Alsaleh, A. (2011). Knowledge Management. Jordan, Amman: Dar Ithra for Publication and Distribution.

Jashapara, A. (2011). Knowledge Management: An Integrated Approach. New York, NY: Prentice Hall.

Kaplan, R., \& Norton, D. (1992). The balanced scorecard-measures that drive performance. Harvard Business Review, 70-79.

Kaplan, R., \& Norton, D. (2008). The Execution Premium Linking Strategy to operations for Competitive Advantage. Boston: Harvard Business School Press.

Kharabsheh, R., Magableh, I., \& Sawadha, S. (2012). Knowledge management practices (KMPs) and its impact on organizational performance in pharmaceutical firms. European Journal of Economics, Finance and Administrative Sciences, 48, 6-15.

Kotecki, P. (2011). Building organizational capability: A study of knowledge Management practices reasons, and Results. PhD. Dissertation, Capella University.

Kotler, P. (2000). Marketing management (The Millennium). New Jersey, NJ: Prentice-Hall.

Matin, H., Alvani, S., Jandaghi, G., \& Pashazadeh, Y. (2010). Designing and clarifying knowledge sharing model in administrative agencies to improve the performance. European Journal of Economics, Finance And Administrative Science, 22, 101-111. 
Mciver, D., \& Hall, C. (2011). Knowledge management processes and firm performance: A contingency perspective. $A M B P P, 148$. http://dx.doi.org/10.5464.AMBPP.2011.148.a

Mitchell, H. (2002). Strategic worth human resources driving organization performance. Universalia, August. Retrieved from http://www.universalia.com/sites/default/files/presentations/fichiers/2002_strategicworthhr_hughmitchell.p $\mathrm{df}$

Momeni, M., Monavarian, A., Shaabani, E., \& Ghasemi, R. (2011). A conceptual model for knowledge management process capabilities and core competencies by SEM the call of ironman automotive industry. European Journal of Social Sciences, 22(4), 437-489.

Montgomery, D. C., Peck, E. A., \& Vining, G. G. (2001). Introduction to linear regression analysis (3rd ed.). New York, NY: John Wiley \& Sons.

Munir, \& Rohindi, D. (2012). Development model for knowledge management system (KMS) to improve university's performance (case study in Indonesia University of Education). International Journal of Computer Science, 9(1), 1-6.

Mustafa, M. (2012). A model of integration between knowledge management and business processes of industrial small and medium-sized enterprises. International Journal of Data Base Management System, 4(4), 13-28. http://dx.doi.org/10.5121/ijdms.2012.4402

Neely, A. (2005). The evolution of performance measurement research. International Journal of Operations and Production Management, 25(12), 1264-1277. http://dx.doi.org/10.1108/01443570510633648

Noruzy, A., Dalfard, V. M., Azhdari, B. S., Salman, N., \& Rezazadeh, A. (2013). Relationship between transformational leadership, organizational learning, knowledge management, organizational innovation, and organizational performance: An empirical investigation of manufacturing firms. The International Journal of Advanced Manufacturing Technology, 64(5-8), 1073-1085.

Ooi, K. (2009). TQM and knowledge management: Literature review and proposed framework. African Journal of Business Management, 3(11), 633-643. Retrieved from http://www.academicjournals.org/journal/AJBM/article-full-text-pdf/374044718487

Othman, M., \& Othman, M. (1997). Total quality requirements to develop the technical Commercial Education curriculum in Egypt. Total Quality Management Conference in Developing the University Education. Zaqazeeq University, Egypt.

Poureisa, A., Ahmadgourabi, M., \& Efteghar, A. (2013). Balanced scorecard: A new tool for performance evaluation. Interdisciplinary Journal of Contemporary Research In Business, 5(1), 974-978. Retrieved from http://journal-archieves32.webs.com/974-978.pdf

Salleh, K. F., \& Huang, C. (2011). Learning organization, knowledge management process and organizational performance: empirical evidence forma public university. Proceedings of the international Conference on Intellectual Capital Knowledge Management, organizational learning.

Sekaran, U., \& Bougie, R. (2009). Research methods for business: A skill-building approach (5th ed.). New York, NY: John Wiley \& Sons Inc.

Seth, A., \& Oyugi, L. (2013). Influence of balanced scorecard on organizational performance in institutions of higher learning in Kenya: A case study of University of Nairobi. International Journal of Education And Research, 1(8), 1-12, August. Retrieved from http://www.ijern.com/journal/August-2013/38.pdf

Shutibhinyo, W. (2012). Balanced scorecard practices and determinants: An empirical study of listed companies in Thailand. Global Conference on Business And Finance Proceedings, 7(1), 58.

Slaihat, T., \& Almahameed, S. (2013). Effect of practicing knowledge management on using Balanced performance card: Field study on the SMEs. Jordanian Journal in Business Administration.

Yaseen, S. (2007). Knowledge management-Concepts, Systems, and Technique. Jordan, Amman: Dar Al-Manahej. 


\section{Copyrights}

Copyright for this article is retained by the author(s), with first publication rights granted to the journal.

This is an open-access article distributed under the terms and conditions of the Creative Commons Attribution license (http://creativecommons.org/licenses/by/3.0/). 